\title{
ANALOGOUS CHARACTERS: TACITUS' LIVIA AUGUSTA AND AGRIPPINA MINOR
}

\author{
M Dircksen (North-West University)
}

\begin{abstract}
Scholarship has recognised Tacitus' preoccupation with character and his use of rhetorical stereotypes even at a time when historiography was examined with the overriding aim of discovering the historical 'truth'. The search for empirical validity revealed Tacitus' historical unreliability and his manipulation of material. Historical theory has since evolved toward an acknowledgement of ancient historiography as a form of literary art and belonging to the domain of narratology. This article is based on the premise that the Annals of Tacitus closely corresponds to a modern literary text and that the 'manipulated material' requires of the reader to fulfil an active role in the interpretation process. A narratological analysis of Tacitus' characterisation of Livia Augusta and Agrippina Minor reveals a sophisticated use of the narratological device of 'analogy between characters'. The analysis is limited to identical nouns and adjectives used in the direct description of both these women and the reinforcement of these characteristics by indirect presentation. Tacitus' mastery of subtle narratological devices becomes evident and his portrayal of Livia as analogous to Agrippina reiterates his deeply seated hatred of the Julio-Claudian regime.
\end{abstract}

Keywords: Tacitus' character portrayal; narratological analysis; Livia; Agrippina Minor; analogy between characters.

\section{The 'literariness' of Tacitus' Annals}

The fact that Cicero refers to classical historiography as opus oratorium maxime (De legibus 1.5) clearly proves that he saw historiography as linked closely to oratory and the important principle of invention. However, under the influence of scholars such as Johann Martin Chladenius and Leopoldt von Ranke, the second half of the $18^{\text {th }}$ century, all of the $19^{\text {th }}$ century and the first decades of the $20^{\text {th }}$ century, saw a rejection of the rhetorical tradition in historical studies in favour of a new claim for empirical validity. Terms such as 'Wissenschaft' and 'source critique' were indicative of this movement away from rhetoric and towards a scientific reflection on historiography (Rüsen 2020:93-94).

The search for 'truth' did not prevent scholars from recognising Tacitus' detailed character portrayal. He was accused of devoting more attention to personalities than to the radical changes which took place on the economic, 
political and sociological front during the first centuries AD. ${ }^{1}$ Tacitus' preoccupation with character and penetrating delineation has been variously explained. Walker (1952:204), recognising rhetorical elements in his work, makes out a very convincing case for the theory that Tacitus used similar models to those provided by his education in rhetoric to portray his historical characters. $^{2}$ These type-characters are presented in recurrent situations and are most persistent where Tacitus handles material involving doubt and where the sharpest conflict between emotion and intellect were provoked. The situations of Livia and Agrippina Minor were very similar. They were both wives of emperors (Livia was married to Augustus and Agrippina Minor to Claudius) as well as mothers of emperors (Livia was the mother of Tiberius and Agrippina of Nero). Walker does not, however, include imperial woman in her list of type-characters and even concludes that the three evil women of Books 11-16, i.e. Agrippina Minor, (wife of the emperor Claudius and mother of Nero), Messalina (wife of Claudius) and Poppaea (Nero's wife) are allowed to be individuals (1952:234).

Hayden White's 1973 masterpiece, Metahistory: The historical imagination in nineteenth-century Europe 'tossed the entire concept of scientific history out the window, claiming that historians are fundamentally artists who imbue historical action with aesthetic and moral purpose' (Dean 2019:1337). ${ }^{3}$ With White's innovation comes the realisation that ancient historiography resembles a literary genre much like the modern historical novel ${ }^{4}$ and as such lends itself to literary analysis. ${ }^{5}$

1 'The vast complex organism of the Roman empire only catches the eye of Tacitus at points where it serves to illustrate the characteristics of a few leading personages who played their part in the social life of Rome itself' (Reid 1921:192). See also Marsh 1931:12.

2 See also Foubert who juxtaposes Agrippina Maior, Livilla, Plancina, Messalina and Agrippina Minor to exemplify Tacitus' technique of parallel lives 'to evoke the image of traditional matronae as a framework with which his audience could evaluate and criticize imperial women' (2010:2).

3 See also Rüsen 2020:97. Woodman uses the terms metahistory with reference to Tacitus' Annals (1988:186).

4 'The classical historians wrote narrative, and narrative history is currently said to be experiencing a revival in its fortunes' (Woodman 1988:197). On the creation of persuasive images and literary strategies in Roman historiography see Schultz 2019.

5 On the rhetorical nature of Roman historiography Woodman 1988:197 writes: ' ... it will be clear that in my view classical historiography is different from its modern namesake because it is primarily a rhetorical genre and is to be classified (in modern terms) as literature rather than as history'. On the literary art of Tacitus, see Daitz 1960 and Watson 1995. 
Judith Ginsburg (2006) took an important step in acknowledging and presenting a literary portrait of the imperial wife and mother, ${ }^{6}$ Agrippina Minor, by 'reminding the reader repeatedly that little can be taken at face value in either the literary or the material record' (Gruen 2006:6). ${ }^{7}$

\section{Narratology and ancient historiography}

Historiography is now widely considered to be a form of narrative with the status of literature and therefore 'belonging to the domain of narratology'. ${ }^{8}$ Motivated by peculiar and personal loyalties and aversions, the author of historiography is at liberty to exercise personal freedom to arrange narrative patterns of event, time, space, narration, focalization, and character in an original and unique way. Embellishments, personal comments, individual style and carefully chosen vocabulary combine to create a very unique version of events and character portrayal. Narratology has its roots firmly anchored in structuralism and can be described as the theory, discourse or critique of narration. Based on the work of A J Greimas and Gerard Genette and refined by Mieke Bal, it provides the reader with a theoretical framework and some clearly defined questions about the artistic characteristics of the text. This set of refined analytical and descriptive tools provided by narratology, has now also found a foothold in classical scholarship. ${ }^{9}$ It seems that the study of classical historiography has come full circle and that there is 'no need to apologize for considering again the relevance of Cicero's discussion for our understanding of the influence of rhetoric on Roman historiography' (Northwood 2008:229)..$^{10}$ Similarities in Tacitus' version of events and the accounts of Suetonius and Dio were once utilised to reveal the 'historical truth' and reflected negatively on Tacitus' historical reliability. In a literary analysis, corresponding facts in the account of the three authors can now be utilised to reveal Tacitus' literary manipulation of material. The artist's literary and artful

6 'What sets Ginsburg's study apart from those of her predecessors is that her focus is not on Agrippina herself, nor on the question of whether she was a positive or negative force, nor does she aim to reconstruct the historical Agrippina from the farrago of information that has survived' (Barret 2008:659).

7 Among the historians who were trying to find the 'real Agrippina' and aiming to establish a 'historical reconstruction' of her times are Syme 1958:437; Dudley 1968:95; Martin 1981:152; Griffin 1984:73; Mellor 1993:44, 53 and Holland 2000:45, 63.

8 'Barthes, one of the founding fathers of narratology, without further discussion considered historiography a form of narrative and hence as belonging to the domain of narratology' (De Jong 2004:8).

9 'The extension of narratological analysis to historiography and generally to nonfictional narrative occurred in the wake of the "narrative turn" in historical studies which is centrally linked to the name of Hayden White' (Fludernik 2005:48).

10 See also Woodman 1988:99-101. 
portrayal is not neutralised by the fact that other sources contain or omit the same material. Tacitus' selection and reworking of the material to enhance his character portrayal are unique to his version of events and portrayal of character.

There is, however, an important condition for the literary analysis of character portrayal in ancient historiography which distinguishes it from fictional texts. The text does not exist only in and through itself. The reader's prior knowledge of the historical and political context and the literary conventions of the time, will determine the competency of her reception of the text (Claassen 1990:65). An informed reader will not, for example, expect character development from ancient historiography (Pitcher 2010:103-104).

The study of Tacitus' portrayal of Agrippina and Livia below is directed and systemised by a narratological framework for the analysis of character. Rimmon-Kenan's 's 'set of analytical procedures' (Rimmon-Kenan 2002:151) is a synthesis of existing theories and provides a very basic and general apparatus for analysis and interpretation, ideally suited to the purpose of the classicist who is perhaps not versed in the specialised discipline of narratology. The analysis below is limited to analogous direct descriptors ${ }^{12}$ of the two imperial women and Tacitus' exemplifying of these traits by indirect portrayal; it is by no means a comprehensive analysis of their characters.

\section{A narratological analysis of Tacitus' analogous portrayal of Agrippina Minor and} Livia Augusta

'There are two basic types of textual indicators of character: (1) direct definition, and (2) indirect presentation. Direct definition names a trait by an adjective ... an abstract noun ... or possibly some other kind of noun ... or part of speech'. Definition provides a general, explicit and static impression, and does not demand of the reader to play an active part in deducing a character trait (Rimmon-Kenan 2002:62-63). A presentation is indirect when it 'displays and exemplifies ... in various ways' rather than explicitly mentioning a character trait (Rimmon-Kenan 2002:61).

11 Although Rimmon-Kenan 2002:1 originally limited the subject of her book, Narrative fiction to the species of narrative called 'narrative fiction', she reflects on the direction narratology has taken in a chapter which was added to the 2020 edition of her book: 'But there was another direction in the discipline: one that sought the differentia specifica not of narrative fiction but of narrative in general, whether fictional or nonfictional, verbal or non-verbal' (2002:141) and on page 152 she states: 'Classical narratology ... can contribute to highlighting the principles underlying all narratives'.

12 On the scarcity of scholarly research of this type i.e. analogy, parallelism or type characters in Tacitus' work, see Foubert 2010:7. 
Tacitus uses identical descriptors (nouns and adjectives) to portray both women, and in this way he is already establishing an association of Livia with Agrippina in the reader's mind. The following eight descriptive words and phrases are used in connection with both women: (1) nobilitas (noble birth) which entitles them to (2) magnificentia (splendour). Their (3) forma (beauty) enhanced their splendour and based on their privileged status they wielded (4) potentia (power), which led to (5) impotentia (lack of restraint). The inevitable result was that they became (6) gravis (burdensome) to the state and its rulers. The adjective (7) muliebris (womanly) describes many of their attributes. Their role as stepmothers, also typifies them as the (8) saeva noverca (cruel stepmother).

These identical descriptors establish an analogy between the characters of the two imperial women (Rimmon-Kenan 2002:73) and is ingeniously reinforced by indirect characterisation which relates to their actions (Rimmon-Kenan 2002:63), appearance, speech (Rimmon-Kenan 2002:65) and the space they occupy in relation to their environment and other characters.

\section{Identical direct descriptors reinforced by indirect character portrayal}

Since Tacitus' depiction of Agrippina is much more detailed than that of Livia, the discussion below is limited to identical terms of definition used of both women (Rimmon-Kenan 2002:62). It is noteworthy that Tacitus does not always take responsibility for information concerning Livia's involvement in underhand and cruel deeds as a means to obtain and retain power for herself and her son. He makes use of unconfirmed rumours and supplies alternative reports. ${ }^{13}$ In this way he shifts the responsibility to his sources, but leaves the reader with the notion that she was very similar to Agrippina.

\section{Nobilitas (noble descent)}

Both Livia and Agrippina Minor were of noble descent and a summary of Livia's life in the form of an obituary provides a typical example of direct definition.

Rubellio et Fufio consulibus, quorum utrique Geminus cognomentum erat, Iulia Augusta mortem obiit, aetate extrema, nobilitatis per Claudiam familiam et adoptione Liviorum Iuliorumque clarissimae. ... nullam posthac subolem edidit sed sanguini Augusti per coniunctionem Agrippinae et Germanici adnexa communis pronepotes habuit.

13 His well-known 'art of innuendo' was noted by Ryberg 1942; Sullivan 1975/6; Miller 1977; Woodman 1988; Whitehead 1979; Develin 1983 and his reporting of rumours by, amongst others, Ries 1969; Shatzman 1974 and Gibson 1998. 
Julia Augusta died in an advanced old age in the consulship of Rubellius and Fufius, both of whom had the surname Geminus. A Claudia by birth and by adoption a Livia and a Julia, she united the noblest blood of Rome ... She had no subsequent issue, but allied as she was through the marriage of Agrippina and Germanicus to the blood of Augustus, her greatgrandchildren were also his (5.1). ${ }^{14}$

Emphasis is placed on her direct descent from Claudian stock and adoption into the house of the Julii. Her illustrious nobility (nobilitatis ... clarissimae) has relevance for the new importance of family connections during the reign of Augustus, since at this time 'the spotlight was on women who stood closest to the throne' and constituted an 'elite within an elite' (Bauman 1994a:99). Her privileged space within the imperial family renders the character traits that Tacitus ascribes to her believable.

Agrippina's familial connections were also unequalled. In the debate amongst Claudius' freedmen to select the most suitable wife for the emperor, the nobility of the candidates was an important factor. The fact that this scene is unique to Tacitus' account is significant since it illustrates the importance he attached to the lineage of imperial wives - they were part and parcel of the detested imperial house of the Julii-Claudii. Pallas wins the argument by reminding the emperor that Agrippina was bringing with her the grandson of Germanicus who would unite the descendants of the Julian and Claudian families (12.2).

This reference to Agrippina's nobility of birth does not come from the authorial voice, but is the first and foremost argument in Vitellius' speech before the senators. Vitellius and all the senators knew only too well that nobility was the most important factor in the choice of a wife for Claudius.

Agrippina was allowed to enter the Capitol in a carpentum, and Tacitus links this event, an instance of rare privilege, to reinforce earlier remarks about her exceptional familial ties: ${ }^{15}$

carpento Capitolium ingredi, qui honos sacerdotibus et sacris antiquitus concessus venerationem augebat feminae, quam imperatore genitam, sororem eius qui rerum potitus sit et coniugem et matrem fuisse, unicum ad hunc diem exemplum est (12.42).

14 All reference to Latin texts are to the Annals of Tacitus. Apart from a few small adjustments, the translation is that of Alfred John Church \& William Jackson Brodrib. (http://classics.mit.edu/Tacitus/annals.5.v.html)

15 'There is also good reason to believe that Livia might at the same time have been offered the privilege of travelling in the carpentum, or covered carriage' (Barret 2002:95). 
She would enter the Capitol in a chariot, a practice allowed of old only to the priests and sacred images. This increased the popular reverence for a woman who up to this time was the only recorded instance of one who, an emperor's daughter, was sister, wife, and mother of a sovereign.

Her position in the carpentum, entering into the space of the Capitolium, linked to the clear reference to her remarkable connections within the imperial family, presents an excellent example of 'space' becoming much more than physical locality.

These descriptions of the 'place' or 'position' both women occupy in relation to their forebears proceed from both the authorial voice and the character of Vitellius, and become very significant indicators of their privileged 'space' within the reign of their husbands and sons, and firmly places Livia in the same category as Agrippina.

\section{Magnificentia (splendour)}

The splendour of the two women is described by the word magnificentia in a remarkable passage where the two ladies are indeed juxtaposed by Tacitus after Nero's succession to the throne:

Caelestesque honores Claudio decernentur et funeris sollemne perinde ac divo Augusto celebratur, aemulante Agrippina proaviae Liviae magnificentiam (12.69).

Divine honours were voted to Claudius, and his funeral solemnities were celebrated precisely as those of the deified Augustus, Agrippina emulating the magnificence of her great grandmother Livia.

Although removed in time, the space they occupied in relation to other characters at the funerals of Augustus and Claudius respectively, emphasises their identical privileged position as wives and mothers of emperors. The different historical times are merged by the identical space which underlines their similarity and makes the identical character traits more believable.

Livia's magnificence is reiterated by the physical space close to Augustus while she accompanied him on his travels (3.34). The senate decided that whenever she entered the theatre, she was to take her place among the seats reserved for the Vestals (4.16). This privileged environment within the theatre elevates her to a position above other mortals and enhances her magnificentia.

Agrippina also occupies a physical space not far (neque procul) from the emperor at the celebration of the engineering feat which linked lake Fucinus to the Liris river (12.56). Her action of presiding (praesidere) with Claudius over this 
occasion reinforces her magnificentia. The first attempt at linking lake and river had failed. After the excavations had been deepened a show was put up to attract a crowd once again. The spectacle included a gladiatorial show and floating pontoons to stage an infantry engagement and a banquet was set up close to the outflow of the lake. Agrippina's magnificentia is enhanced by the lavish environment created for the unveiling of the engineering project. ${ }^{16}$ When the sluices were opened, the water gushed forth, sweeping away everything in its path. Agrippina, surrounded by splendour and opulence inveighed against Narcissus the manager of the project, accusing him of avarice and peculation. The irony would not have been lost on Tacitus' contemporaries.

The physical space of both women was clearly exceptionally and scandalously close to that of the emperor, an important metaphor for their splendour which was also not far removed from that of the emperor.

\section{Impotens/impotentia (lack of restraint)}

Direct characterisation of Livia as 'impotens' comes from the authorial voice. In the same obituary referred to above, Tacitus follows the praise of Livia's noble descent with a direct definition of her powerful position as a mother: She was 'mater impotens'. ${ }^{17}$

sanctitate domus priscum ad morem, comis ultra quam antiquis feminis probatum, mater impotens, uxor facilis et cum artibus mariti, simulatione filii bene composita (5.1.3).

In the purity of her home life she was of the ancient type, but was friendlier than was thought fitting in ladies of former days. An imperious mother and an amiable wife, she was a match for the diplomacy of her husband and the dissimulation of her son.

Another reference to Livia's impotentia occurs when Tacitus comments on the less than amiable relationship between mother and son (4.51). Tiberius chose to spend his last days away from Rome. According to Tacitus, the other historians suggest that he did this to escape from the intrigues of Sejanus, or more likely, to find an inconspicuous home for the cruelty and lust which his acts proclaimed to the world. However, there were those who believed that in his old age he had become

16 'But indirect presentation may also rely on a relation of spatial contiguity' (RimmonKenan 2002:67).

17 See Keitel 1977:200. Impotentia connotes lack of self-control and immoderate behaviour; see also Rutland 1987:15-16. 
sensitive to his outward appearance. And then, placed in the prominent last position, Tacitus adds:

Traditur etiam matris impotentia extrusum quam dominationis sociam aspernabatur neque depellere poterat, cum dominationem ipsam donum eius accepisse (4.57).

It is also reported that he was driven into exile by his mother's lack of restraint (matris impotentia), whose partnership in his power he could not tolerate, while it was impossible to cut adrift one to whom he held that power.

Tiberius' human environment ${ }^{18}$ i.e. separated from the inhabitants of Rome, is indicative of his reclusive character. In narratological terms this is a 'traitconnoting metonymy'. In Livia's case 'the relation of contiguity is ... supplemented by that of causality'. Her space, removed from her son, was caused by her impotentia. In Tacitus' narration, Tiberius' departure from Rome is a metonymy for Livia's overbearing personality.

The word 'impotentia' is also used in connection with Agrippina. This attack on her character is attributed to Narcissus who had acted as director of failed project which linked lake Fucinus with the Liris river (12.57). When the outburst of water resulted in chaos, it caused panic amongst the bystanders. Playing on the emperor's alarm, Agrippina placed the blame on Narcissus. He was not to be silenced and accused Agrippina of a female lack of self-control (impotentiam muliebrem) and extravagant ambition (nimias spes). ${ }^{19}$ Her reaction to the disaster illustrates a lack of self-control. She knew that the emperor, in his shocked state, would support her attack on the culprit, Narcissus, who was not an ally but an obstacle in her quest for power. This attack on Agrippina's impotentia does not come from the authorial voice and therefore does not qualify as direct characterization. ${ }^{20}$ Tacitus uses indirect discourse to create an impression, without taking full responsibility for the utterance. The implication is that even a freedman like Narcissus could recognise her lack of self-control and ambition. In a few short sentences, Agrippina is characterised as unable to control herself.

In narratological terms there is a metonymic relation between external appearance and character traits (Rimmon-Kenan 2002:68). Both Livia and

18 For environment used as 'trait-connoting metonymies' see Rimmon-Kenan 2002:69-70.

19 Both Dio Cassius and Suetonius confirm the allegation of negligence in the construction of the tunnel, but Tacitus is the only one to link the incident to his portrayal of Agrippina.

20 'Such naming of a character's qualities counts as direct characterization only if it proceeds from the most authoritative voice' (Rimmon-Kenan 2002:62). 
Agrippina were blessed with physical attractiveness. ${ }^{21}$ Although such a description of imperial women is perhaps formulaic, Tacitus 'often links physical beauty to spiritual corruption' (Barret 2002:102). ${ }^{22}$ Tacitus uses the same word (forma) to describe the physical appearance of both Livia and Agrippina and the context is significant. Augustus, smitten by Livia's beauty (forma), took her from her husband (5.1). Her beauty was the cause of Augustus' immoral act. ${ }^{23}$ There can be little doubt that Agrippina was also blessed with physical beauty. ${ }^{24}$ Beauty was a prerequisite for the candidates who wished to marry Claudius and it was certainly an asset flaunted by both Claudius' prospective wives themselves (12.1) and the freedman who promoted each of them (12.2).

When Tacitus compares Agrippina to her rival Domitia Lepida (12.64), he finds that there was very little to choose between the two of them as far as looks (forma), age and fortune were concerned, and immediately follows up with a comparison of other corresponding negative traits: both were shameless, infamous, and intractable, and were rivals in vice as much as in the advantages they had derived from fortune. The negative context in which her beauty is mentioned taints her comely appearance and provides a derogatory slant.

\section{Potentia (power)}

The abstract noun (Rimmon-Kenan 2002:61) potentia is used in connection with Livia in Ann. 4.21: Calpurnius Piso spurned Livia's influence (potentia) when he dragged her friend Urgulania from the palace to court. This trait is reiterated in Ann. 4.12: The feud between Livia and her archenemy, the popular and ambitious Agrippina Maior, could easily be exploited by those whom the Augusta trusted, since Livia was 'an old woman by nature anxious to maintain her power' (anum suapte natura potentiae anxiam 4.12).

Her actions exemplify and reinforce Livia's potentia. She had a hold over the aged Augustus (devinxerat 1.3). She overpowered him to such an extent that he banished his only remaining grandson, Agrippa Postumus, to Planasia. According to Watson (1995:81) the verb devincio literally means 'bind to one emotionally'. ${ }^{25}$ Tiberius' advancement after the demise of all his rivals was due to his mother not as before by her secret diplomacy (matris artibus) but openly through her

21 Images of Livia portray 'ageless and elegant beauty' (Barret 2002:103); according to Dio 54.19.3 Augustus made Terentia and Livia compete in a beauty contest.

22 Poppaea (13.45) is also described as being a woman of beauty (forma).

23 From Vitellius' speech in the senate (12.6) it is clear that the taking of married women at will (ad libitum) by Caesars was frowned upon (procul a praesenti modestia).

24 Dio twice (60.31.6, 61.14.2) calls Agrippina kale (beautiful).

25 This same word is used (11.28) to describe the hold that Messalina had over Claudius: iuxori devinctum. 
encouragement (hortatu 1.3). The direct descriptor is thus displayed by her actions. In this passage, Livia's complicity in the death of Augustus' adopted grandsons Lucius Caesar and Gaius is also hinted at. They were cut off either by fate or by the treachery of their stepmother Livia. She openly promoted Tiberius' claims and arranged the exile of Agrippina Maior (1.3.3-4). Later Tiberius could not thrust her aside because he had received this very power as her gift (neque depellere poterat, cum dominationem ipsam donum eius accepisset 4.57).

Exercising her power, Livia often interceded on behalf of friends such as Haterius (1.13) and Urgulania (2.34 and 4.21). Gnaius Piso, governor of Syria who was suspected of wanting to get rid of Germanicus, was assured by an intimate associate that he enjoyed the conscientia (joint knowledge) of the Augusta (2.77). She also had a hand in the pardon of Plancina $(3.15,17 ; 6.26)$, who was eventually accused of the murder of Germanicus.

The first chapters of Book 12 centre on Agrippina's rise to power. The environment (Rimmon-Kenan 2002:69) she creates enhances her potentia: everything was under the control of a woman (cuncta feminae oboediebant 12.7), and it was a stringent and so to say masculine despotism (adductum et quasi virile servitium 12.7).

Agrippina's actions equally imply and reinforce this trait. She did not leave it to Pallas alone to convince Claudius to marry her. He was charmed by her allurements (adiuta Agrippinae inlecebris 12.3), and not yet his wife, she enjoyed the power of a wife (nondum uxor potentia uxoria iam uteretur 12.3). Once she was certain of her marriage to Claudius, she intrigued for a match between Domitius, the son of Agrippina and her first husband Ahenobarbus, and the emperor Claudius' daughter Octavia (12.3). Nero acquired equality with Britannicus, thanks to the zeal of his mother (studiis matris 12.9). The word potentia is also the direct descriptor of the power Agrippina held over her son: 'Everyone was eager for the power of Nero's mother to be broken' (cupientibus cunctis infringi potentiam matris ... 14.1). During the reign of Nero she could listen in on senate meetings from behind a curtain. This physical space i.e. being close enough to hear, while not visible, becomes a metaphor for her increasing importance within the empire. She is moving ever closer to the level of the emperor in her importance. When an Armenian deputation was pleading their case before Nero, she was preparing to ascend the emperor's tribunal and to share his presidency, had not Seneca admonished the sovereign to step down and meet his mother (13.5) ${ }^{26}$ Her space within the narrative is moving ever closer to the position of the emperor, and this is now evident to all present.

26. This incident is not mentioned by Suetonius and Dio (61.3) links it to a weakness in the management of the state. 
Her use of sexual enticement as a means to obtain and maintain power, surfaces again in 12.7: 'at home there was nothing unchaste unless it was in aid of power' (nihil domi impudicum, nisi dominationi expediret). Although Tacitus admits that his sources are not in agreement about Agrippina's purported sexual advances towards Nero, he reports that one source (Cluvius) suggests that it was motivated by her ardour to keep her influence (ardore retinendae ... potentiae 14.2). ${ }^{27}$ Tacitus adds credence to this rumour by adding that some authors supported this version, since Agrippina had a reputation for using seduction to secure dominatio. The connotation of dominatio is even more pejorative than potentia (Ginsburg 2006:19). Her typically female (muliebriter) use of sex is restricted to actions that would ensure potentia and eventually dominatio. ${ }^{28}$

Just like Livia, she rewarded her supporters and got rid of those who opposed her. Agrippina procured the safety of Seneca (12.8), but arranged for the prosecution of Lollia, her rival for the emperor's hand (12.22), of Lepida (12.65) and of Calpurnia, on whose beauty Claudius had casually commented. She saw to it that Lusius Geta and Rufrius Crispinus were discharged from the command of the praetorian cohorts in favour of Afranius Burrus, who knew that he owed this position to Agrippina (12.42). She obtained the pardon of her principuus propugnator (foremost champion), Vitellius, not merely through her precibus (prayers) but also by her threats (minis). Soon after Nero's accession to the throne, she had a hand in the death by poison of Junius Silanus, brother of Lucius Silanus, ${ }^{29}$ (Octavia's fiancé) as she feared his vengeance (12.59). It is also hinted that she was the reason for Narcissus' suicide. He was suspicious of her and knew that she would be the cause of his downfall (12.42).

In their efforts to elevate their sons to the position of emperor, both women are implicated in the death of her husband, the emperor. It is noteworthy that Livia's complicity in Augustus' death is stated as part of a rumour (quidem ... suspectabant 1.5). However, this passing allusion to Livia's possible complicity is motivated by a detailed discussion of why she would want him dead: there was talk of reconciliation between Augustus and Agrippa Postumus. The seed of suspicion

27 It should be noted here that Suetonius restricts his version to Fabius Rusticus' account and tells us Nero was the instigator (Nero 28). Dio (61.11) prefers Cluvius' account, but does not link the incident to Agrippina's lust for power.

28 The word dominatio surfaces again in 12.4: Vitellius, who had an eye for despots, (ingruentium dominationum provisor) ingratiated himself with Agrippina.

29 According to Dio (60.31), it was in the interest of the freedmen that Silanus should be killed, and they were the cause of his death. Suetonius mentions Silanus' suicide as an example of Claudius' subservience to his wives and freedmen, but makes no specific mention of Agrippina (Claudius 44). 
has been planted and the connection with Agrippina's detailed murder of her husband established.

After Tiberius had been summoned from Illyricum, Livia had the house and streets closely guarded; from time to time optimistic communiques were sent out, and only after all necessary precautions had been taken was it announced that Augustus had passed away and that Tiberius was the new emperor (1.5.1). ${ }^{30}$

A whole chapter is devoted to Agrippina's careful planning and execution of Claudius' poisoning $(12.66,67)$ and, according to Tacitus, the detail of the murder was well attested by the authors of the time (12.67). After Claudius' death, while his body was being kept warm with bandages and blankets, Agrippina, apparently heartbroken (velut dolore evicta), held Britannicus, told him how much he looked like his father, and prevented him and his sisters from leaving the room. She barred all avenues of approach with pickets, and intermittently sent out notices that the condition of the emperor was improving: she wanted to keep the troops in good spirits and was waiting for the auspicious moment insisted upon by the astrologers (12.68).

The actions of the two women after the death of their respective husbands show remarkable similarity: not making the announcement of death known until her son has been acknowledge as the new ruler, the posting of pickets around the house and the issuing of positive reports about the emperor's health. ${ }^{31}$ The similarities led Charlesworth (1927:55-57) to argue that Tacitus based his version of Livia's behaviour on rumours of Agrippina's role in the death of Claudius. It is more likely that the similarity of their acts reveal a purposeful choice and manipulation of material to reinforce a character trait that they shared - a typical lust for potentia.

Their lust for power and lack of control rendered both women burdensome (gravis) to their sons. Livia is described as gravis in rem publicam mater, (as a mother, she was burdensome to the state (1.10), while Nero also regarded his mother as praegravem when he decided to kill her (14.3).

30 Velleius (2.123) reports that Augustus himself recalled Tiberius, and died peacefully in his arms. He makes no mention of Livia. Dio knows of both versions but regards the version in which Tiberius arrived after Augustus' death as more reliable (Dio 56.31.1). Suetonius uses one version in his life of Augustus (98.5) and the other in his life of Tiberius (21.1.22).

31 For discussions of the similarities see Martin 1955:123-128; Syme 1958:1.306, 2.482, 692; Shotter 1965:359-361; Ginsburg 2006:32. 


\section{Muliebris (typical of a woman)}

The adjective muliebris (= typical of a woman) is often used to describe attributes of both Livia and Agrippina. Tacitus' use of muliebris in combination with impotentia (12.57) defines 'lack of restraint' as 'typical of women'.

Livia's feelings of jealousy and hatred towards Agripppina Maior, are also qualified as muliebres offensiones (1.33). According to Tacitus there was no doubt that in the same way that Tiberius had given his instructions to $\mathrm{Cn}$. Piso, new governor of Syria to suppress Germanicus' ambitions, Augusta, who was inspired by feminine jealousy (aemulatione muliebri) to persecute Agrippina Maior, gave her orders to Piso's wife, Plancina (2.43).

Agrippina was also guilty of emotions that are typically feminine. She destroyed Domitia Lepida because of feminine reasons (muliebribus causis 12.64). Nero was angry at those who supported Agrippina's female arrogance (superbia muliebris 13.14). ${ }^{32}$ Agrippina's actions confirm this impression created by direct definition. In her reaction to Nero's love affair with the freedwoman Acte, she ranted and raved as only a woman can, muliebriter fremere (13.13).

Sed Agrippina libertam aemulam, nurum ancillam aliaque eundem in modum muliebriter fremere ...

Agrippina inveighed against her rival, the freedwoman and her daughter in law the slave girl.

A very sophisticated and subtle narrative technique is at work here, that of 'free indirect discourse' (FID). Some theoreticians consider 'free indirect discourse' a principal characteristic of narrative fiction, since the central tradition of the novel is constituted by texts which are not unitary in their discourse ('monological') but polyphonic (Rimmon-Kenan, 2002:119).

FID is grammatically and mimetically intermediate between direct and indirect speech, and gives the idea of combining direct discourse with indirect discourse. Both the narrator's voice and a character's (Agrippina's) pre-verbal perception or feeling can be detected (Golomb 1968:251-262). Agrippina speaks through the voice of the narrator and the two voices fuse. ${ }^{33}$

Tacitus, the authorial voice, tells us that women also tend to be gullible when it comes to good news. Agrippina was willing to believe rumours that Nero wanted reconciliation because of the 'easy faith of women in the agreeable'

32 Ginsburg 2006:42 n. 66 'I doubt Nero actually used the expression superbia muliebris - this is an intrusion of the narrative voice'.

33 For a more detailed account of FID see Mc Hale 1978; Rimmon-Kenan 2002:113; Golomb 1968:251-62 and Pascal 1977. 
'facili feminarum credulitate ad gaudia', 14.4. This remark confirms the underlying negative portrayal of the potentia of women: although they occupied powerful positions, they were prone to the feminine characteristic of credulity.

\section{Saeva noverca (cruel stepmother)}

The literary stereotype of the saeva noverca (cruel stepmother) had been prominent in Roman literature and rhetoric from the late Republic (Ginsburg 2006:107). She would have been a well-known character in both drama ${ }^{34}$ and comedy, the latter especially providing excellent material..$^{35}$

The use of stereotypes is a form of direct definition since it is both explicit and supra-temporal. The well-known character of the wicked stepmother would conjure up the image of an intriguing, wicked and murderous woman who did not shy away from murdering her stepchildren or husband if it would be advantageous to her own offspring. Both Livia and Agrippina are stereotypical stepmothers and in this they are analogous to the figure created in the reader's mind based on prior knowledge of such characters in Roman comedy and drama.

In his portrayal of both Livia and Agrippina Tacitus exploits this topos to the utmost. ${ }^{36}$ It was in her role as stepmother that Livia brought about Tiberius's adoption by Augustus and then his succession to imperial power by removing the emperor's direct descendants. Tacitus ascribes the death of the two foremost contenders for the succession, Gaius and Lucius Caesar, ${ }^{37}$ to either fate (mors fato propera) or the treachery of their stepmother Livia (novercae Liviae dolus 1.3). She also influenced the aged Augustus to banish his only grandson Agrippa Postumus (of whom she was the step-grandmother) to Planasia (1.3). The idea of a stepmother's hatred is repeated with the eventual murder of Augustus' only remaining grandson, Agrippa. Tacitus doubts whether Augustus actually gave the order for the deed or whether it was more probable that Livia and Tiberius

34 Mendell ascribes the clarity of Tacitus' characters to 'his tendency to regard history as a series of dramas in which the characters have a determining influence'. He highlights several elements of the drama in the depiction of Agrippina Minor (1970:138).

35 For an endorsement of Ginsburg's work on the influence of rhetorical tropes and characterisations from Roman comedy on the Tacitean Agrippina, see Harders 2009:281. Ginsburg 2006:23 recognises the assimilation of the main characters in Tacitus' narrative to other stock comic figures such as the servus fallax (Pallas), the matrona imperiosa (Agrippina) and the senex stultus (Claudius).

36 For a detailed analysis of Tacitus' portrayal of Livia and Agrippina as evil stepmothers see Watson 1995:176-192; Ginsburg 2006:106-112.

37 Livia was strictly speaking not the stepmother of Gaius and Lucius Caesar nor of Agrippina Maior (Barret 2001:172-173). 
hastened his death, the former driven by step-motherly hatred (novercalibus odiis) and the latter by fear (1.6). Tacitus supplies alternative (more believable) causes for the unfortunate deaths of Tiberius' potential rivals, but by exploiting the rhetorical connotations of the cruel stepmother, the reader will remember Livia in this role. ${ }^{38}$

As mentioned before, Tacitus reports the rumour of Livia's involvement in Augustus' demise (et quidam scelus uxoris suspectabant, 1.5.1). At his funeral, hostile members of the crowd commented on the role of the stepmother in Augustus' domestic problems: 'last of all, there was Livia, burdensome to the State as a mother, burdensome to the house of the Cæsars as a stepmother' (postremo Livia gravis in rem publicam mater, gravis domui Caesarum noverca, 1.10). This provides another example of 'free indirect discourse'. Tacitus does not vouch for the historical truth, there is no direct quotation, and although the remarks are subtly ascribed to the crowd, the reader is influenced to believe that Livia was perceived by the people as gravis. In reference to a person's character the word gravis could mean 'influential' or 'dignified', but in this particular context the negative connotation of 'overbearing' and 'difficult to bear', even 'disastrous' (Ginsburg 2006:108) is clear enough.

Livia was also plagued by 'a stepmother's bitterness' towards Germanicus' wife, Agrippina Maior (novercalibus ... stimulis; Ann. 1.33). Julia, Agrippina Maior's sister, survived an exile of 20 years, supported by the charity of Augusta. This good deed is given a negative slant by the following comment: 'Augusta, who secretly destroyed her stepchildren when they were enjoying prosperity, and openly made a pretence of her compassion toward them when they fell' (quae florentes privignos cum per occultum subvertisset, misericordiam erga adflictos palam ostentabat 4.71). As the stepmother of Claudius' son Britannicus, Agrippina Minor is also a perfect candidate for the rhetorical image of the saeva noverca. At the opening of Book 12, a debate takes place amongst Claudius' freedmen about the perfect wife for the princeps. When Pallas stresses the fact that Agrippina will bring 'the grandson of Germanicus' (12.2.3) to the imperial household, the inevitable scenario of the wicked stepmother would not have been lost on the audience (Ginsburg 2006:109; Watson 1995:194). Agrippina makes use of the persuasive power of Pallas to ensure that Claudius adopts Nero (12.25-26), and Nero also prematurely assumes the toga virilis (12.41-42) to cement the plans for his future. The reaction of Britannicus is poignant: 'gradually forsaken by the very slaves who waited on him, he turned into ridicule the ill-timed attentions of his

38 'Due to the untimely death of so many of Augustus's heirs, Livia was easy to depict along these lines, and Tacitus pushes the trope at every opportunity' (Ginsburg 2006:131). 
stepmother, perceiving their insincerity' (desolatus paulatim etiam servilibus ministeriis perintempestiva novercae officia in ludibrium vertebat, intellegens falsi 12.26). At the Circensian games, Nero is decked out in triumphal attire while Britannicus wears the toga virilis which is befitting for an immature boy, anticipating their respective destinies (12.41). The subjunctive mood (spectaret; praesumeret) creates the impression that the reader is privy to Agrippina's plans ${ }^{39}$ and thus constitutes another example of FID. She wanted the people to become used to the sight of Nero's superior status.

At Agrippina's instigation Claudius replaced his son's best instructors with substitutes provided by his stepmother (datosque a noverca custodiae eius imponit 12.41). This reference to Britannicus's loss of influence pre-empts Agrippina's attempts to diminish his standing at the imperial court. When, after Nero's adoption Britannicus greeted his stepbrother by addressing him as 'Domitius', a name he no longer had since he was now known as Ti. Claudius Nero Caesar, Agrippina saw this as the first sign of discord and contempt of his adoption. She convinced Claudius to remove all his son's freedmen incorrupta fide (of incorruptible fidelity) and his best teachers. He was placed under the custody of the substitutes provided by his stepmother (datosque a noverca custodiae eius imponit 12.41). ${ }^{40}$ The portrayal of Agrippina as the proverbial cruel and ruthless stepmother is borne out by the treatment of her stepson.

\section{Conclusion}

In the narratological analysis of character above, the concept of 'historical truth' on which Tacitus based his characterisation of Livia and Agrippina is reduced to 'some hard core of information ... merely required to elaborate ... in a manner which was plausible as true to life' (Woodman 1988:78). In narratological terms this is referred to as the 'story'. By identifying similar direct indicators of the characters of the two women and examining how these traits are displayed and exemplified in the text, Tacitus' portrayal of two analogous characters becomes evident. This unique art of character portrayal has often led to negative reflections on his historical reliability. The type characters are often the result of selecting and manipulating source material and, as Barret (1996:xiv) warns, the tailoring of the evidence to fit into some imaginary, preconceived type model, is a dangerous practice.

39 See Ginsburg 2006:110.

40 This incident is not mentioned by Suetonius, while Dio (60.32) does not link the removal of Britannicus' loyal teachers to Agrippina's influence over Claudius. 
It is safe to say that in Tacitus' narrative, Livia and Agrippina fulfil similar roles within identical circumstances and that Tacitus has exploited this analogy to the detriment of Livia. ${ }^{41}$ By clever repetition of words and tricks of rhetoric and storytelling, Tacitus has, even in the absence of clear fact, elaborated on these similarities and has created a character type, i.e. wife and mother of an emperor and stepmother to the legitimate claimants to the succession. The analogy that exists between Tacitus' portrayal of the two imperial women smacks of precisely the kind of 'type casting' identified by Walker, the literary topoi Ginsburg refers to and Foubert's parallel lives. Although this reflects negatively on Tacitus' reliability as an historian, the subtle reinforcement of the superficial impressions created by direct definition is a testimony to his literary genius.

In his portrayal of Livia Tacitus created a literary character, who was a prototype of Agrippina: an influential woman who secured the throne for her son, ruthlessly got rid of any opposition, was a burden to the state, and an evil stepmother who showed no restraint and who was as emotional as only a woman could be. ${ }^{42}$

There is a thematic concern which influences (even determines) Tacitus' characterisation of Livia to fit into a pre-established mould. Not only aspects of Livia's character are revealed 'but also potential constituents of non-character constructs, such as the work's ideology' (Rimmon-Kenan 2002:40). A deeply seated hatred of the Julio-Claudian regime lies at the core of Tacitus' exploitation of analogous characters. ${ }^{43}$ His negative portrayal of Agrippina and Livia as typical imperial wives is a clear manifestation of his overarching critique and abhorrence of the imperial system. ${ }^{44}$

At the conclusion of the analysis I return to Hayden White and his support of the concept of the 'practical past' and 'his repeated attempts to shepherd disciplinary historians toward a deeper and more adequate understanding of our relationship to the past as well as their own role in making that past into history' (Kleinberg 2018:692).

41 See Rimmon-Kenan 2002:72 for 'analogy between characters'.

42 Bauman 1994b:187 argues that the attack on Livia was in full swing long before Tacitus' day.

43 'On this one topic it is generally recognised that Tacitus was the weak brother, his portrait of Livia vitiated both by his deepseated contempt for the Julio-Claudian family and by his unshakable conviction that the ambitious woman was evil incarnate' (Barret 2002:ix).

44 'In the end, the contrived representations, whatever their relation to reality, reveal the face presented by the regime and the means designed to describe it' (Ginsburg 2006:8). 


\section{BIBLIOGRAPHY}

Barret, A A 1996. Agrippina: Sex, power, and politics in the early empire. New Haven/London: Yale University Press.

2001. Tacitus, Livia and the evil stepmother. RMF 144.2:171-175.

2002. Livia: First lady of imperial Rome. New Haven, Conn: Yale University Press.

2008. Review article. Ginsburg, J. Representing Agrippina: Constructions of female power in the early Roman Empire. IJCT 15.4:659-661.

Bauman, R A 1994a. Women and politics in ancient Rome. London: Taylor \& Francis Group.

-1994b. Tanaquil-Livia and the death of Augustus. Historia: Zeitschrift für alte Geschichte 43.2:177-188. Online available:

www.jstor.org/stable/4436324 [12 June 2020].

Charlesworth M P 1927. Livia and Tanaquil. CR 41:55-57.

Claassen, J-M 1990. The role of (ancient) history in the interpretation of (classical) literature. Akroterion 35:60-67.

Daitz, S G 1960. Tacitus' technique of character portrayal. AJPh 81:30-52.

Dean, C J 2019. Metahistory: The historical imagination in nineteenth-century Europe, by Hayden White. The American Historical Review 124.4.13371350.

De Jong, I J F 2004. Narrators, narratees, and narratives in ancient Greek literature. In Nünlist, R, et al. (eds.), Studies in ancient Greek narrative 1, Mnemosyne Supplement 257. Leiden: Brill.

Develin, P 1983. Tacitus and techniques of insidious suggestion. Antichthon 17:64-95.

Dudley, D R D 1968. The world of Tacitus. London: Secker \& Warburg.

Fludernik, M 2005. Histories of narrative theory (II): From structuralism to the present. In Phelan J \& Rabinowitz P J (eds.), A companion to narrative theory, 36-59. Oxford: Blackwell.

Foubert, L 2010. Literary constructions of female identities: The parallel lives of Julio-Claudian women in Tacitus' Annals. In Deroux, C (ed.), Studies in Latin literature and Roman history 15, 344-365. Brussels: Peeters.

Gibson, B 1998. Rumours as causes of events in Tacitus. Materiali e discussioni per l'analisi dei testi classici 40:111-129.

Ginsburg, J 2006. Representing Agrippina: Constructions of female power in the early Roman Empire. New York: Oxford University Press.

Golomb, H 1968. Combined speech - A major technique in the prose of SY Agnon: Its use in the story 'A different face' (in Hebrew), Ha-Sifrut 1.2:251262. English summary, i-ii. 
Griffin, M T 1984. Nero: The end of a dynasty. London / New York: Routledge. Harders, A 2009. Review: Representing Agrippina. Constructions of female power in the early Roman Empire by Judith Ginsburg. Gnomon 81. 3:280-282.

Holland, R 2000. Nero: The man behind the myth. Stroud: Sutton.

Kleinberg, E 2018. Hayden White: In memoriam. Historian 80.4:691-704.

Marsh, F B 1931. The reign of Tiberius. Oxford: Oxford University Press.

Martin, R H 1955. Tacitus and the death of Augustus. CQ 5.1-2:123-128. 1981. Tacitus. Bristol: Bristol Classical Press. (Repr. with corr. 1994).

Mc Hale, B 1978. Free indirect discourse: A survey of recent accounts. Poetics and theory of literature 3:294-387.

Mellor, R 1993. Tacitus. New York: Routledge.

Munn, M 2017. Why history? On the emergence of historical writing. In Howe, T, Müller, S \& Stoneman, R (eds.), Ancient historiography on war and empire, 2-23. Oxford: Oxbow Books.

Northwood, S J 2008. Cicero De oratore 2.51-64 and rhetoric in historiography. Mnemosyne 61:228-244.

Pascal, R 1977. The dual voice: Free indirect speech and its functioning in the nineteenth-century European novel. Manchester: Manchester University Press.

Pitcher L 2010. Characterization in ancient historiography. In Marincola J (ed.), A companion to Greek and Roman historiography, 102-117. Oxford: WileyBlackwell.

Reid, J S 1921. Tacitus as a historian. JRS 11:191-199.

Ries, W 1969. Gerucht, Gerede, öffentliche Meinung. Interpretationen zur Psychologie und Darstellungskunst des Tacitus. Diss. Heidelberg.

Rimmon-Kenan, S 2002. Narrative fiction. Taylor \& Francis Ltd / Books.

Available at: https://search-ebscohost (Accessed 7 May 2020).

Rüsen, J 2020. A turning point in theory of history: The place of Hayden White in the history of metahistory. History and Theory 59.1:92-102.

Rutland, L W 1978. Women as makers of kings in Tacitus' Annals. CW 1.72:1529.

Ryberg, I S 1942. Tacitus' art of innuendo. TAPhA 73:383-404.

Shatzman, I 1974. Tacitean rumours. Latomus 33:549-578.

Sullivan, D 1975/6. Innuendo and the 'weighted alternative' in Tacitus. CJ 71:312326.

Syme, R 1958. Tacitus. Oxford: Clarendon Press.

Walker, B 1952. The Annals of Tacitus: A study in the writing of history. Manchester: Manchester University Press.

Watson P A 1995. Ancient stepmothers: Myth, misogyny \& reality. Leiden / New York: Brill. 
White, H 1973. Metahistory: The historical imagination in nineteenth-century Europe. Baltimore: Johns Hopkins University Press.

Whitehead, D 1979. Tacitus and the loaded alternative. Latomus 38:474-495.

Woodman, A J 1988. Rhetoric in classical historiography: Four studies. London / Sydney: Routledge. 